\title{
Corporate Social Responsibility on SKI KEHATI Index Corporate Performance: A Case Study
}

\author{
S. Wahyudi ${ }^{1}$, I.R.D. Pangestuti ${ }^{2}$, R.D. Laksana ${ }^{3}$, Hersugondo ${ }^{4}$, Robiyanto ${ }^{5}$
}

\begin{abstract}
:
Many companies are now increasingly aware of the importance of implementing Corporate Social Responsibility (CSR) as part of their business strategy and as the embodiment of the company's concern to society.

This study specifically examines the SRI-KEHATI Index which is a new index that specifically includes issuers that have excellent performance in encouraging sustainable businesses, as well as having awareness of the environment, social and good corporate governance using an analysis technique that is regression weight in structural equation modelling used to examine the relationship between the variables.

The model for this research is illustrated by the path diagram. It proves that the environment influences the company's financial performance, showing that the better the environmental performance, the respondent will respond positively through the fluctuations in the company's stock price which can improve the company's financial performance. The higher the corporate governance, the higher the corporate performance will be.

Corporate Social Responsibility disclosure activities have a significant influence on the company's financial performance. The higher the social responsibility, the higher the corporate performance SRI-KEHATI. The strength of the theory of organizational legitimacy in the content of corporate social responsibility in developing countries has two elements; first, the capability to place profit maximization motives and second this makes a clearer picture of the company's motivation to increase its social responsibility.
\end{abstract}

Keywords: SRI-KEHATI index, Corporate Social Responsibility, Indonesia Stock Exchange.

JEL code: G10, G40, Q50.

\footnotetext{
${ }^{1}$ Diponegoro University, Indonesia, sugengwahyudi@ undip.ac.id

${ }^{2}$ Diponegoro University, Indonesia, irenerinidp1960@gmail.com

${ }^{3}$ Jenderal Soedirman University, Indonesia, riodhani@unsoed.ac.id

${ }^{4}$ Diponegoro University, Indonesia, gondoarum65@gmail.com

${ }^{5}$ Satya Wacama Christian University, Indonesia robiyanto@staff.uksw.edu
} 


\section{Introduction}

The company is not only expected to be a profit-making organization. But it is also required to contribute directly to the public. Many companies are now increasingly aware of the importance of implementing Corporate Social Responsibility (CSR) as part of their business strategy and as the embodiment of the company's concern to the community. Companies can gain legitimacy by demonstrating social responsibility through CSR disclosure in the media including the company's annual report (Ivanova and Bikeeva, 2016; Savina, 2016; Suryanto et al., 2017).

In terms of the economy aspect, company needs to have a system of good corporate governance (GCG), which can provide effective protection to shareholders and creditors and to convince them about the profitability of the investment with a reasonable high value. It also can ensure that company meets the interests of employees and the company's interests. Based on this, it appears that the application of GCG is very imperative for the company. Executive compensation now more widely becomes an interest in the literature. In the financial economics literature based on the agency theory perspective, the researcher was curious to investigate the linkage between compensation structure and a number of variables such as firm performance. Another research also investigated the relationship between executive pay and various aspects such as craning management, industrial regulation, strategic interactions, and social comparisons (Anderson and Bizjak, 2013).

The increasing public demand for transparency and accountability encourages companies to implement good corporate governance (GCG). One implementation of GCG in the company is the corporate social responsibility (CSR). CSR has grown widely all over the word today (Giannakopoulou et al., 2016). According to ISO 26000 , CSR is defined as the responsibility of organization for the impacts of its decisions and activities on society and the environment, through transparent and ethical behavior that contributes to sustainable development, including health and the welfare of the society; it takes into account the expectations of stakeholders; it is in compliance with applicable law and consistent with international norms of behavior; and it is integrated throughout the organization and practiced in its relationship. Therefore, companies tend to focus on sustainability compared to profitability (Wahyudi et al., 2018; Grima and Caruana, 2017; El Chaarani, 2017).

The World Business Council for Sustainable Development (2000) has also explained CSR as the continuing commitment by business to behave ethically and contribute to economic development while improving the quality of life of the workforce and their families as well as of the local community and society at large. In Indonesia, Undang-undang Perseroan Terbatas No.40 (2007) has a quite similar description of CSR. CSR is the commitment of the company to participate in the sustainable economic development to improve the quality of life and environmental benefits the company itself, the local community and society in general. In the SRI-KEHATI Index, a new index on the Indonesia Stock Exchange that specifically contains 
issuers that have excellent performance in encouraging sustainable enterprises, and have a good awareness of the environment, social and corporate governance.

SRI-KEHATI Index as one of the best performers indices was consistent with Robiyanto (2017) findings. SRI-KEHATI was formed from 27 stocks chosen selectively by using financial criteria such as total asset, Price to Earnings Ratio (PER), and free float ratio; also, fundamental factors such as environmental, community, corporate governance, human rights, business behavior, and labor practices and decent works. It is not surprise if SRI-KEHATI stocks are bestperforming stocks in the Indonesia Stock Exchange.

This research focused on executive compensation as a dependent variable because in the corporate governance line especially in Indonesia is still weak so it is interesting phenomena to be analyzed and why even though this executive compensation is higher the performance and good corporate governance in a company are still optimal that can be reflected in the less profit, or decrease and fluctuation in companies' earning and bumping policies (Arvanitis et al., 2017).

Empirical evidences about the relationship between corporate governance firm performance and executive compensation are mixed. For example, Aduda, (2011) argues that the design of optimal executive compensation perspective is to balance the conflicts between the managers and shareholders. Further, the structure of optimal salary or compensation is a trade-off between different incentive problems and risk-sharing considerations. His finding suggests that accounting measures performance, for example ROA, ROE, NPM are not an important point that affects the executive compensation, other findings are the compensation as it was significant affecting executive compensation.

Additionally, Conyon and He (2011) investigated the association between corporate governance and executive compensation in China's public traded firms. As it is consistent with agency theory, their study finds that executive compensation is positively correlated to frim performance. Their study also shows that executive compensation and CEO incentives are lower in state controlled firms and firms with concentrated ownership structures. Moreover, their study finds that firms will have a higher pay-for-performance link when it has more independent directors.

\section{Methodology}

This study uses SRI-KEHATI Index daily closing data from the Indonesia Stock Exchange during the period January 2013 to December 2017. This research is different from the previous study to make casual or reciprocal testing the relationship between corporate performance and executive compensation, and focus on the relationship between corporate governance and executive compensation, add RNCs and transparency financial information as corporate governance structure and using two proxies of firm performance that are return on assets and Tobins's Q with 
control variables such as firm size leverage and growth. Based on this description the relationships between the variables are shown in the following research framework in Figure 1. Corporate governance (size of board commissioners, board commissioners meeting, board commissioner's education, independent commissioners, audit committee size, institutional ownership remuneration and nomination committees, transparency financial information), corporate performance (Tobins' Q, ROA) can affect executive compensation. Meanwhile, executive compensation can also affect corporate performance.

Table 1. Variable Definition and Measurement

\begin{tabular}{|c|c|c|c|}
\hline $\begin{array}{l}\text { Variable/ } \\
\text { Construct }\end{array}$ & Definition & Scale of measurement & $\begin{array}{l}\text { Type of scale } \\
\text { measurement }\end{array}$ \\
\hline $\begin{array}{l}\text { Executive } \\
\text { Compensation }\end{array}$ & $\begin{array}{l}\text { In this study used the } \\
\text { proxy for compensation } \\
\text { level that is the total } \\
\text { compensation level for the } \\
\text { board member. (Andreas } \\
\text { et al., 2010) }\end{array}$ & $\begin{array}{l}\text { Ln_EC = Natural log of } \\
\text { compensation of CEO to total board } \\
\text { members }\end{array}$ & Ratio \\
\hline $\begin{array}{l}\text { Board Size of } \\
\text { Commissioner } \\
\text { s }\end{array}$ & $\begin{array}{l}\text { Size of the board of } \\
\text { commissioners here is the } \\
\text { number of members of the } \\
\text { board of commissioners of } \\
\text { the company, which was } \\
\text { set in the number of units } \\
\text { (Isshaq and Zangina, } \\
\text { 2009) }\end{array}$ & $\begin{array}{l}\text { Size of Board Commissioners }= \\
\text { Number of Board Commissioners }\end{array}$ & Nominal \\
\hline $\begin{array}{l}\text { Board } \\
\text { Commissioner } \\
\text { s Meeting }\end{array}$ & $\begin{array}{l}\text { Board commissioners } \\
\text { meeting is the number of } \\
\text { meeting done by board } \\
\text { commissioners in a year. }\end{array}$ & $\begin{array}{l}\mathrm{BCM}=\text { Number of meeting done by } \\
\text { board commissioners in a year }\end{array}$ & Nominal \\
\hline $\begin{array}{l}\text { Board } \\
\text { Commissioner } \\
\text { s Education }\end{array}$ & $\begin{array}{l}\text { Board commissioner's } \\
\text { education is the number of } \\
\text { board commissioners that } \\
\text { have accounting and } \\
\text { business degree. }\end{array}$ & $\begin{array}{l}\mathrm{BCE}=\mathrm{BOC} \text { with accounting or } \\
\text { business degree to total board }\end{array}$ & Ratio \\
\hline $\begin{array}{l}\text { Independent } \\
\text { Commissioner } \\
\mathrm{s}\end{array}$ & $\begin{array}{l}\text { Independent } \\
\text { commissioner is the } \\
\text { number of commissioners } \\
\text { that independent. }\end{array}$ & $\begin{array}{l}\text { IC = independent commissioners to } \\
\text { total board }\end{array}$ & Ratio \\
\hline $\begin{array}{l}\text { Audit } \\
\text { Committee } \\
\text { Size }\end{array}$ & $\begin{array}{l}\text { Audit committee size is } \\
\text { the number of audit } \\
\text { committee that a company } \\
\text { have. }\end{array}$ & $\begin{array}{l}\mathrm{AC}=\text { The number of audit } \\
\text { committee that a company owned }\end{array}$ & Nominal \\
\hline $\begin{array}{l}\text { Institutional } \\
\text { Ownership }\end{array}$ & $\begin{array}{l}\text { Institutional ownership is } \\
\text { the percentage of share } \\
\text { from the company that } \\
\text { owned by the institutional } \\
\text { outside company. }\end{array}$ & $\begin{array}{l}\text { IO }=\% \text { of ownership company } \\
\text { owned }\end{array}$ & Ratio \\
\hline RNCs & $\begin{array}{lrr}\text { RNCs is the } & \text { total } \\
\text { compensation } & \text { from } \\
\text { Remuneration } & \text { and } \\
\end{array}$ & $\begin{array}{l}\text { RNCs = Natural log of total amount } \\
\text { of RNCs compensation }\end{array}$ & Ratio \\
\hline
\end{tabular}




\begin{tabular}{|c|c|c|c|}
\hline & Nomination Committees & & \\
\hline $\begin{array}{l}\text { Transparency } \\
\text { financial } \\
\text { information }\end{array}$ & $\begin{array}{l}\text { Transparency financial } \\
\text { information is the index } \\
\text { for the transparency } \\
\text { financial information. }\end{array}$ & $\begin{array}{l}\text { TFI = The number of transparency } \\
\text { in financial information index / total } \\
\text { index transparency }\end{array}$ & Ratio \\
\hline Tobins' Q & $\begin{array}{l}\text { Tobins' } Q \text { is the value of } \\
\text { the firm }\end{array}$ & $\begin{array}{l}\text { Stock price times number of shares } \\
\text { outstanding to total book value of } \\
\text { net assets (total equity) }\end{array}$ & Ratio \\
\hline $\begin{array}{l}\text { ROA (Return } \\
\text { on Assets) }\end{array}$ & $\begin{array}{l}\text { ROA is calculated based } \\
\text { on EAT (Earning After } \\
\text { Tax) divided by total } \\
\text { assets. Companies that } \\
\text { have high profitability } \\
\text { expected time required to } \\
\text { complete the audit will be } \\
\text { shorter than firms with the } \\
\text { low profitability (Dogan et } \\
\text { al., 2007) }\end{array}$ & ROA $=\frac{\text { EAT }}{\text { Total Asset }}$ & Ratio \\
\hline Firm Size & $\begin{array}{l}\text { Firm size is a scale which } \\
\text { can be classified } \\
\text { according to the size of } \\
\text { the company in many } \\
\text { ways. In this research, } \\
\text { company size is the size of } \\
\text { the company examined by } \\
\text { public accountant and is } \\
\text { calculated using the total } \\
\text { assets owned by the } \\
\text { company or the } \\
\text { company's financial } \\
\text { statements that have been } \\
\text { audited using the log size. } \\
\text { Measurement of Company } \\
\text { Size is by the natural } \\
\text { logarithm of total assets } \\
\text { (Ahmad and Abidin, } \\
\text { 2008) }\end{array}$ & $\begin{array}{l}\text { Company Size }=\text { Natural log of } \\
\text { Total Assets }\end{array}$ & Nominal \\
\hline Growth & $\begin{array}{l}\text { Growth is the company } \\
\text { percentage of delta sales } \\
\text { from year to year. }\end{array}$ & Growth $=\frac{\text { Sales } \mathrm{t}-\text { Sales } \mathrm{t}-1}{\text { Sales } \mathrm{t}-1}$ & Ratio \\
\hline Leverage & $\begin{array}{l}\text { Shaumitra (2002) } \\
\text { measured leverage } \\
\text { variable that proxied by } \\
\text { divided by total debt over } \\
\text { total equity. It shows how } \\
\text { many assets were funded } \\
\text { by company's debt. }\end{array}$ & DER $=\frac{\text { Total Debt }}{\text { Total Equity }}$ & Ratio \\
\hline
\end{tabular}


Figure 1. SEM Path

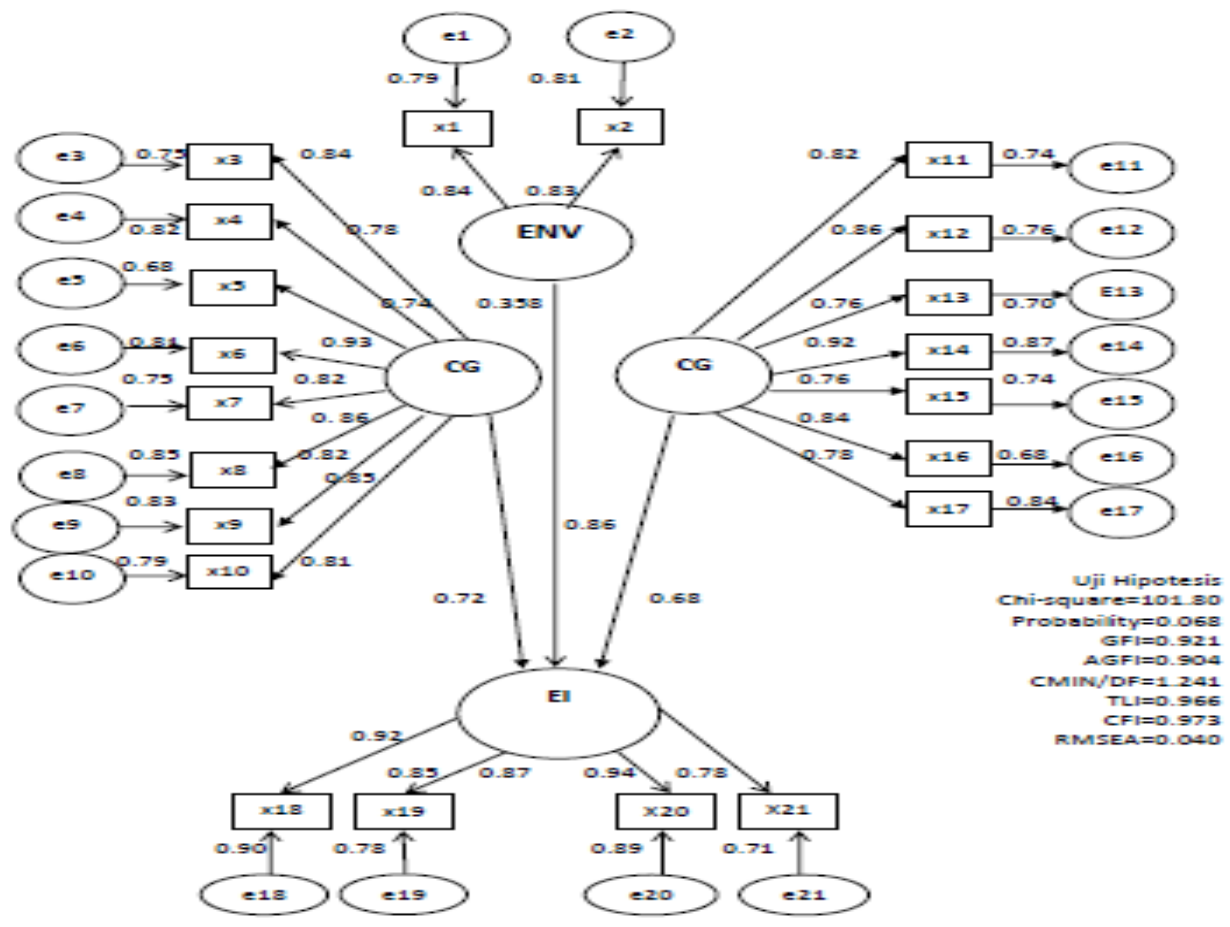

Table 2. Regression weight full model

\begin{tabular}{|l|l|l|l|l|l|l|}
\hline Variable & Min & Max & Skew & c.r. & kurtosis & c.r. \\
\hline Growth & $-1,062$ & 11,471 & 3,409 &, 999 & 1,409 & 2,007 \\
\hline Days & 1.000 & 3.000 & 2.121 & 1.322 &, 6465 & 1,324 \\
\hline ROA &,- 633 & 1,063 & 1,976 & 1,211 & 2,137 & 1,236 \\
\hline TobinsQ & $-2,245$ & 7,606 & 3,693 & 2,129 & 2,362 & 2,650 \\
\hline TFI &, 070 &, 987 &, 688 & 1,643 &,- 447 & $-1,832$ \\
\hline RNCs & 16,321 & 27,846 &,- 096 &,- 790 & 1,348 & 1,533 \\
\hline IO &, 041 &, 999 &,- 577 & $-2,733$ &,- 154 &,- 632 \\
\hline ACS & 1,000 & 8,000 & 2,759 & 2,639 & 1,015 & 2,298 \\
\hline IC & 1,000 & 5,000 &, 915 & 1,507 &, 449 & 1,842 \\
\hline BCE &, 167 & 1,000 &, 393 & 3,224 &,- 805 & $-2,304$ \\
\hline BCM & 1,000 & 57,000 & 3,822 & 1,366 & 1,939 & 1,600 \\
\hline BSOC & 2,000 & 11,000 &, 905 & 2,427 &, 645 & 1,647 \\
\hline Multivariate & & & & & 8,145 & 9,792 \\
\hline
\end{tabular}


Table 3. Regression weight full model

\begin{tabular}{|l|l|l|l|l|l|l|l|}
\hline & & & Estimate & S.E. & C.R. & P & Label \\
\hline CP & $<---$ & CV &,- 266 &, 102 & $-2,611$ &, 009 & par_11 \\
\hline BSOC & $<---$ & GCG & 1,000 & & & & \\
\hline BCM & $<---$ & GCG &, 832 &, 278 & 2,995 &, 003 & par_1 \\
\hline BCE & $<---$ & GCG &,- 023 &, 008 & $-2,866$ &, 004 & par_2 \\
\hline IC & $<---$ & GCG &, 495 &, 038 & 13,033 &, 000 & par_3 \\
\hline ACS & $<---$ & GCG &, 167 &, 024 & 7,029 &, 000 & par_4 \\
\hline IO & $<---$ & GCG &,- 016 &, 007 & $-2,368$ &, 018 & par_5 \\
\hline RNCs & $<---$ & GCG &, 215 &, 050 & 4,308 &, 000 & par_6 \\
\hline TFI & $<---$ & GCG &,- 006 &, 008 &,- 726 &, 468 & par_7 \\
\hline Days & $<---$ & CP & 1,000 & & & & \\
\hline ROA & $<---$ & CP &, 113 &, 036 & 3,150 &, 002 & par_8 \\
\hline Days & $<---$ & CV &,- 086 &, 038 & $-2,251$ &, 024 & par_9 \\
\hline FS & $<---$ & CV & 1,077 &, 200 & 5,348 &, 000 & par_10 \\
\hline
\end{tabular}

Table 4. Regression Parameter Estimation weight

\begin{tabular}{|l|l|l|l|l|l|l|l|}
\hline & & & Estimate & S.E. & C.R. & P & Label \\
\hline ROA & $<--$ & GCG &, 374 &, 062 & 2,420 &, 044 & par_11 \\
\hline ROA & $<---$ & Growth &, 495 &, 332 & 2,812 &, 005 & par_12 \\
\hline ROA & $<---$ & Days &,- 266 &, 102 & $-2,611$ &, 009 & par_13 \\
\hline
\end{tabular}

\section{Results and Discussion}

\subsection{Hypothesis Testing 1}

Hypothesis 1: The higher the environment, the higher the corporate performance will be. Estimation parameters between environment variables and SRI-KEHATI corporate performance showed significant results with C.R values. $=2.57$. Research conducted by Fitriani (2013) proves that the environment influences the company's financial performance, indicating that the better the environmental performance, the investor will respond positively through the company's stock price fluctuations that can improve the company's financial performance. This will affect the company's income and profit which is an indicator of financial performance.

So, based on the above explanation environmental performance can be taken into consideration to see the company's financial performance because a positive image of the company can increase public interest in purchasing company products that will make financial performance to increase (company profits increase). Increased 
financial performance will increase stock prices and the value of the company's shares that attract investors to invest in the company (Laksana et al., 2017). Companies that have good environmental performance are also good for investors and potential investors so that investors will respond positively through fluctuations in the company's stock price (Gardana, 2013). The results of Fitriyani's (2013) study suggest that environmental performance has a significant influence on financial performance. Likewise, Restuningdiah (2010) found a positive relationship because there was a significant influence between environmental performance on financial performance.

If the company has an environmental performance and a good reputation for the environment, this is included in one of the achievements of the company that can balance the quality of the company, because in addition to efforts to generate maximum profit the company also pays attention to environmental performance which is often ignored by the company. This achievement can generate investor and community interest in producing assets in the company or has given consumers' confidence that the products produced are also produced in a good environment. So more and more investors and public trust companies that have good environmental performance, the profitability of the company will automatically grow.

\subsection{Hypothesis Testing 2}

Hypothesis 2: The higher the corporate governance, the higher the corporate performance will be. The estimated parameters between SRI-KEHATI environment and corporate performance variables show significant results with C.R values. = 2.57. As a form of corporate responsibility towards the community and other stakeholders, companies are often involved in corporate social responsibility activities. Communities and stakeholders can respond positively to companies involved in corporate social responsibility activities. Positive responses provided by the community and stakeholders in the form of trust and acceptance of products produced by the company can improve the company's operations, and this will have implications for the improvement of the company's financial performance (Sihotang, 2012). Based on the research of Sudaryanto (2011), Melisa (2013) and Elda (2013), Corporate Social Responsibility disclosure activities have a significant influence on the company's financial performance.

Corporate Social Responsibility is a concept or action taken by a company (according to the ability of the company) as a form of their responsibility for the social or environment in which the company is located. Financial performance is a description of the financial condition of a company that is analyzed with financial analysis tools, so it can be known about the good and bad financial condition of a company that reflects work performance in a certain period. Financial performance in this study is measured using profitability. Profitability is part of the results of management performance that can identify the success of the company in a certain period. 
This is evidenced by a descriptive analysis that shows that the value of Corporate Social Responsibility is good, it shows that the Corporate Social Responsibility implemented by the company can be accepted by the community well. It is suspected that the company's Corporate Social Responsibility disclosure takes place in accordance with the system and values that apply to the community and explains that the company needs to disclose corporate governance in order to create a good corporate image of investors.

\subsection{Hypothesis Testing 3}

Hypothesis 3: The higher the social responsibility, the higher the corporate performance will be. Estimation parameters between environment variables and corporate performance SRI-KEHATI showed significant results with C.R values. = 2.57. Barkemeyer (2007) revealed that the explanation of the strength of the theory of organizational legitimacy in the content of corporate social responsibility in developing countries has two elements; first, the capability to place profit maximization motives makes a clearer picture of the company's motivation to increase its social responsibility. Second, organizational legitimacy can include cultural factors that shape the pressure of different institutions in different contexts. Disclosure of corporate social responsibility is done to get positive value and legitimacy from the community. Legitimacy theory can also be used to explain the linkages of corporate governance mechanisms and profitability to the disclosure of corporate social responsibility.

\section{Conclusions, limitations, recommendations}

Based on the analysis data, the conclusion in this research is as follows: corporate governance, including number board size of commissioners, board commissioner's meeting, board commissioner's education, independent commissioner, audit committee size, institutional ownership, corporate performance, including ROA and Tobin's Q has a positive and significant influence on executive compensation. There is interrelationship between corporate performance, including ROA and Tobin's Q and executive compensation. Disclosure of corporate social responsibility is done to get positive value and legitimacy from the community. Legitimacy theory can also be used to explain the linkages of corporate governance mechanisms and profitability to the disclosure of corporate social responsibility.

As a form of corporate responsibility towards the community and other stakeholders, companies are often involved in corporate social responsibility activities. Communities and stakeholders can respond positively to companies involved in corporate social responsibility activities. Positive responses provided by the community and stakeholders in the form of trust and acceptance of products produced by the company, as a result can improve the company's operations, and this will have implications for the improvement of the company's financial performance. 
Limitation of the study does not analyze the impact of corporate governance toward corporate performance. Another limitation is this study only uses two proxies for corporate performance that include ROA and Tobin's Q.

The recommendations in this research are as follows: The company can pay attention to the factors affecting executive compensation which include commissioners board size, meeting board commissioners, education of board commissioners, independent commissioners, audit committee size, remuneration and nomination committees, transparency Tobin's Q and ROA because these variables affect the executive compensation. The future research can add more variables affecting executive compensation or make the moderating variables, such as CEO personal reputation, managerial ownership, committee audit effectiveness, number board of directors, board diversity, age of company, type industry capability, corporate social responsibility, and firm value. In addition, further research also can add another proxy for corporate performance, such as ROE (Return on Equity), ROI (Return on Investment), or PBV (Price Book Value).

\section{References:}

Altiza, M. 2007. Effects of Trading Days on Stock Returns: An Analysis of Efficient Market Anomalies. Journal of Management Sciences, 3(1), 31-42.

Arvanitis, E.S., Stamatopoulos, V.Th. and Chatzimarkaki, M. 2017. Cash and Ownership on Firms Market Value: Evidence from Greek Panel Data. International Journal of Economics \& Business Administration, 5(1), 70-91.

Ariel, R.A. 1987. A Monthly Effect in Stock Returns. Journal of Financial Economics, 18(1), 161-174.

Bollerslev, T. 1986. Generalized Autoregressive Conditional Heteroscedasticity. Journal of Econometrics, 31, 307-327.

Brockman, P., Michayluk, D. 1998. Individual Versus Institutional Investors and the Weekend Effect. Journal of Economics and Finance, 22(1), 71-85.

Brooks, R.M. 1997. The Individual Investor and the Weekend Effect: A Reexamination with Intraday Data. Quarterly Review of Economics and Finance, 37(7), 725-737.

Cahyaningdyah, D., Witiastuti, S.R. 2010. Monday Effect and Rogalski Effect Analysis on the Jakarta Stock Exchange. Journal of Management Dynamics, 1(2), 154-168.

Corhay, A., Tourani Rad, A. 1994. Statistical Properties of Daily Stock Returns: Evidence From European Stock Markets. Journal of Business Finance \& Accounting, 21(2), 271-282.

Coutts, J.A. 1999. Friday the Thirteenth and the Financial Times Industrial Ordinary Shares Index 1935-94. Applied Economics Letters, 6(1), 35-37.

Coutts, J.A., Mohamed A.Sheikh. 2002. The Anomalies that Aren't there: The Weekend, January and Pre-Holiday Effects on the All Gold Index on the Johannesburg Stock Exchange 1987-1997. Applied Financial Economics, 12, 863-871.

El-Chaarani, H. 2017. The Mutual Impacts of Corporate Governance Dimensions and Legal Protection Systems on the Performance of European Banks: A Post-Crisis Study. European Research Studies Journal, 20(2A), 538-567.

Fama, E.F. 1970. Efficient Capital Markets: A Review of Theory and Empirical Work. Journal of Finance, 25(2), 383-417. 
Fitriyani, I., Ratna Sari, M.M. 2013. January Effect Analysis on LQ-45 Index Shares in the Indonesia Stock Exchange in 2009-2011. Accounting E-Journal of Udayana University, 4(2), 421-438.

Frieder, L., Subrahmanyam, A. 2004. Nonsecular Regularities in Returns and Volume. Financial Analysts Journal, 60(4), 29-34.

Giannakopoulou, N.E., Stamatopoulos, V.T. and Thalassinos, I.E. 2016. Corporate governance in shipping: An overview. Maritime Policy and Management, Vol. 43(1), 19-38

Grima, S., Seychell, S. and Bezzina, H.F. 2017. Investigating Factors Predicting Derivative Mishandling: A Sociological Perspective. European Research Studies Journal, 20(4A), 3-17.

Ivanova, A.I., Bikeeva, V.M. 2016. Corporate Social Responsibility: Specificity, Formation Mechanism, Estimation of Management Efficiency. European Research Studies Journal, 19(3) Part A, 167-184.

Kamath, R.R., Chakornpipat, R., Chatrath, A. 1998. Return Distributions and The Day-ofthe-Week Effects in the Stock Exchange of Thailand. Journal of Economics and Finance, 22(2-3), 97-106.

Laksana, R.D, Hersugondo, H., Wahyudi, S., Muharam, H. 2017. The New Decomposition Asset Growth Effect. An Empirical Evidence of Indonesia, Journal of Applied Economic Sciences, 12(4), 977-984

Lakonishok, J., Maberly, E. 1990. The Weekend Effect: Trading Pattern of Individual and Institutional Investors. Journal of Finance, 45(1), 231-224.

Lucey, B.M. 2000. Friday the 13th and the Philosophical Basis of Financial Economics. Journal of Economics and Finance, 24(3), 294-301.

Lucey, B.M. 2001. Friday the 13th: International Evidence. Applied Economics Letters, 8(9), 577-579.

Lutfiaji, and Atim Djazuli. 2012. The Day of The Week Effect, Week Four Effect and Rogalski Effect Testing Against Returns on LQ-45 Stocks on the Indonesia Stock Exchange. Working Paper, 1-11.

Martikainen, Teppo, Jukka Perttunen, and Vesa Puttonen. 1995. Finnish Turn-of-the-Month Effects: Returns, Volume, and Implied Volatility. Journal of Futures Markets, 15(6), 605-615.

McGuiness, P.B. 2006. Turn-of the-Month Return Effects for Small Cap Hong Kong Stocks. Applied Economics Letters, 13, 891-898.

McGuiness, P.B., Richard D.F.H. 2011. Comparison of the "Turn-of-the-Month" and Lunar New Year Return Effects in Three Chinese Markets: Hong Kong, Shanghai and Shenzhen. Applied Financial Economics, 21, 917-929.

Nikkinen, J., Sahlstrom, P., Aijo, J. 2007. Turn-of-the-Month and Intramonth Effects: Explanation From the Important Macroeconomic News Announcement. Journal of Futures Markets, 27(7), 105-126.

Ogden, J.P. 1990. Turn-of-Month Evaluations of Liquid Profits and Stock Returns: A Common Explanation for the Monthly and January Effects. Journal of Finance, 45(4), 1259-1272.

Pearce, D.K. 1996. The Robustness of Calendar Anomalies in Daily Stock Returns. Journal of Economics and Finance, 20(3), 69-80.

Robiyanto. 2000. Effect of Stock Trading Day Against Stock Daily Returns on the Jakarta Stock Exchange (A Study of JCI, Sectoral Stock Index and Featured Stock Index (LQ 45)). Business Strategy Journal, 5, 46-94.

Savina, N.T. 2016. The Institutionalization of the Concept of Corporate Social 
Responsibility: Opportunities and Prospects. European Research Studies Journal, 19(3) Part B, 56-76.

Shah, S.M., Rehman, U.A., Syed Nisar, A. 2014. The Ramadhan Effect on Stock Market. European Academic Research, 1(11), 4712-4720.

Sias, R.W., Starks, T.L. 1995. The Day-of-the-Week Anomaly: The Role of Institutional Investors. Financial Analysts Journal, May/June, 58-67.

Suryanto, T., Thalassinos, E.J., Thalassinos, I.E. 2017. Board Characteristics, Audit Committee and Audit Quality: The Case of Indonesia. International Journal of Economics \& Business Administration, 5(3), 47-57.

Zwergel, B. 2010. On the Exploitability of the Turn-of-the-Month Effect - An International Perspective. Applied Financial Economics, 20, 911-922. 